\title{
A Pedunculated Fibrolipomatous Polyp of Tonsil: A Rare Case Report
}

\author{
Dheeraj Lambor, Surender Kumar, Nabha S. Kakodkar, Sneha Sose \\ Department of ENT, Goa Medical College, Bambolim, India \\ Email: dr.morodia@gmail.com
}

How to cite this paper: Lambor, D., Kumar, S., Kakodkar, N.S. and Sose, S. (2017) A Pedunculated Fibrolipomatous Polyp of Tonsil: A Rare Case Report. International Journal of Otolaryngology and Head \& Neck Surgery, 6, 16-21.

https://doi.org/10.4236/ijohns.2017.62004

Received: January 12, 2017

Accepted: March 10, 2017

Published: March 13, 2017

Copyright (c) 2017 by authors and Scientific Research Publishing Inc. This work is licensed under the Creative Commons Attribution International License (CC BY 4.0).

http://creativecommons.org/licenses/by/4.0/

\begin{abstract}
Lipoma being the most common mesenchymal tumour of the body is rare in head and neck region. Fibrolipoma is a rare benign tumour of palatine tonsil which may present a pedunculated lesion in oropharynx and can cause dysphagia, foreign body sensation in throat, sleep disturbance and voice change. Our patient presented with foreign body sensation in throat. Examination showed pedunculated polypoidal mass arising from right palatine tonsil, treated with tonsillectomy under general anaesthesia. Histopathological examination confirmed as fibrolipoma of tonsil. Malignant transformation in fibrolipoma is very rare but some cases have been reported. Hence patient was followed up for two years and no recurrence noted.
\end{abstract}

\section{Keywords}

Palatine Tonsil, Lipoma, Fibrolipoma

\section{Introduction}

Palatine tonsil is a part of Waldyer's ring. In oropharynx, tonsillar region is the most common site for malignancy. Benign tumours like fibroma, lipoma, hamartomatous polyp, fibrolipomatous polyp and lymphangiomatous polyp are relatively rare [1]. Lipoma is most common mesenchymal tumour in the body but in head and neck region, it constitutes only $15 \%$ of occurrence which mainly includes parotid, oral cavity, hypopharynx and larynx [1]. Few cases of fibrolipoma are also reported in nasopharynx and Eustachian tube ostium [2]. Fibrolipomatous polyp in tonsillar region is even rarer tumour as the tonsillar tissue lacks the adipose tissue [1]. Pedunculated lesions in palatine tonsil can be very distressing by causing dysphagia, foreign body sensation in throat and by mimicking like malignant lesion. So we present this rare case report to discuss differential diagnosis of benign pedunculated polypoidal lesions in oro- 
pharynx.

\section{Case Report}

Our patient is 29 years old male presented with a complaint of foreign body sensation in throat and history of (h/o) noticing painless mass (Figure 1) in throat since 2 months which was progressively increasing in size. He also complained of mass moving up and down with movements of swallowing. There was no h/o difficulty in swallowing, breathing or speech. There was no history of weight loss or excessive salivation. On examination, there was single yellowish pedunculated lobulated mass approximately $2.5 \times 2 \times 1 \mathrm{~cm}$ in dimensions, arising from medial surface of the upper pole of right tonsil which was soft in consistency and non-pulsatile. There was no surrounding induration and mass didn't bleed on touch. Rest of medial surface of tonsil and both anterior and posterior pillars were normal. Rest of ENT (ear, nose and throat) examination was normal and there was no significant lymphadenopathy in Head and Neck region. Provisional diagnosis was benign tumours of tonsil like lipoma, fibroma, lymphangiomatous polyp and fibrolipomatous polyp. A plain and contrast computerised tomography scan (CT scan) showed a non-enhancing, exophytic, polypoidal, pedunculated lesion originating from medial surface of right palatine tonsil measuring approx. $2 \times 1.4 \mathrm{~cm}$ in dimensions, showing fat attenuation values with few specs of calcification (Figure 2). Deeper tissues were not involved and there was no significant lymphadenopathy. Patient was investigated thoroughly for excision of mass with tonsillectomy under general anaesthesia. Intraoperatively, it was noted that mass was originating from the Crypta Magna (Figure 3). The mass was excised in total with tonsillectomy by extracapsular dissection method (Figure 4). When the specimen was put in water, the mass floated which suggested it being the lipoma. Cut sections of the specimen showed mass as multilobulated and soft but hard in the centre (Figure 5). Histopathologically, it showed lymphoid germinal centres lined with non-keratinizing stratified squamous epithelium with stroma filled with adipose tissue and variable amount fibrous tissue (Figure 6). Patient was followed up for 2 years and no recurrence was noted. Patient also consented for publication of his case report.

\section{Discussion}

The polypoidal lesions in the tonsils include various neoplastic and non-neoplastic lesions like inflammatory polyp, hemangioma, lymphangioma, lipoma, fibrolipoma, schwannoma, lymphangiectesia, atrio-venous malformation, hamartoma, juvenile angiofibroma, fibroepithelial polyp and pedunculated squamous papilloma [3]. The nomenclature of these tumours depends upon the proliferation of various tissue like lymphoid tissue, blood vessels, adipose tissue, fibrous tissue and the squamous epithelium. With increase in time, there is increase in fatty tissue, lymphoid tissue and blood vessels which results in benign tumours like lipoma and lymphangioma [3]. Among these only hamartoma and squamous 


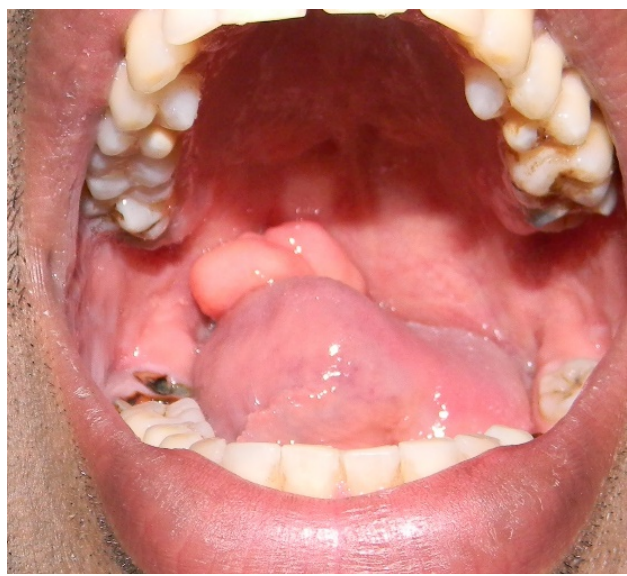

Figure 1. Showing polypoidal tissue originating from right palatine tonsil.

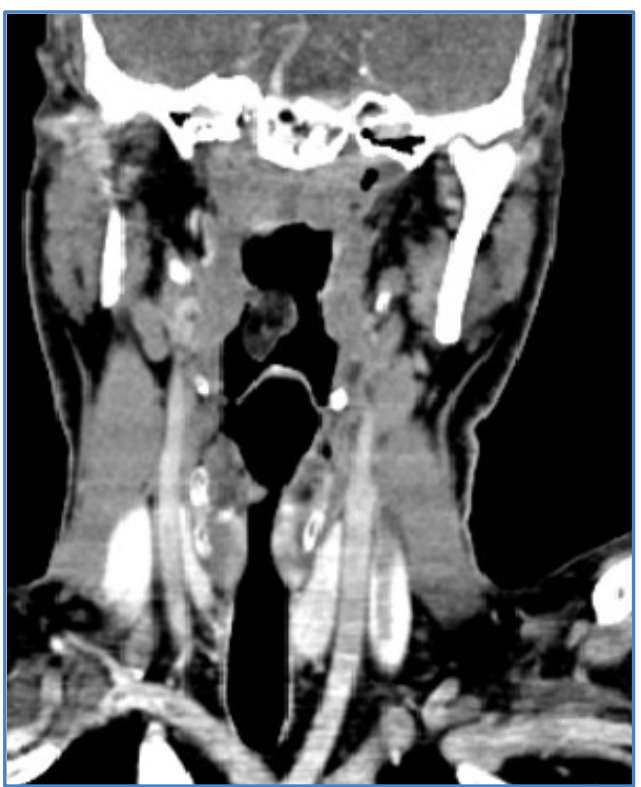

Figure 2. Plain and contrast enhanced CT coronal view showing a non-enhancing, exophytic, polypoidal pedunculated lesion originating from medial surface of right palatine tonsil measuring approx. $2 \times 1.4 \mathrm{~cm}$ in dimensions, showing fat attenuation values with few specs of calcification.

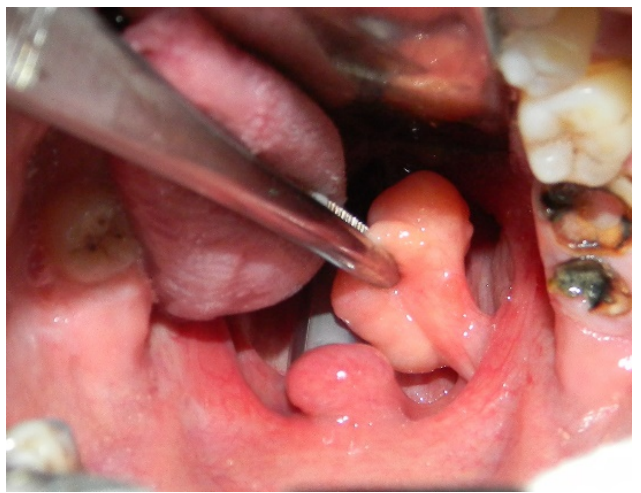

Figure 3. Intraoperative picture showing pedunculated polyp attached to superior pole of right tonsil. 


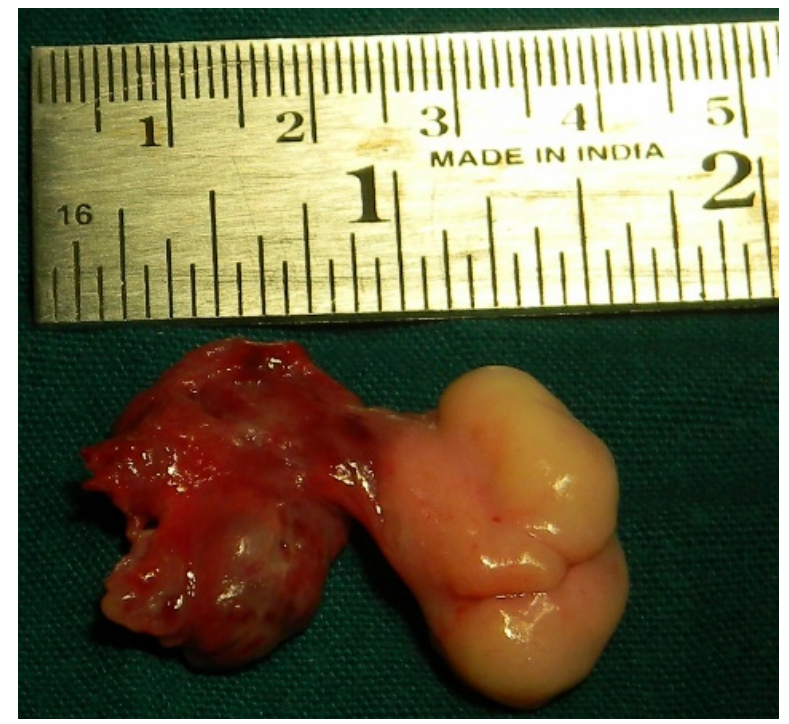

Figure 4. Postoperative specimen.

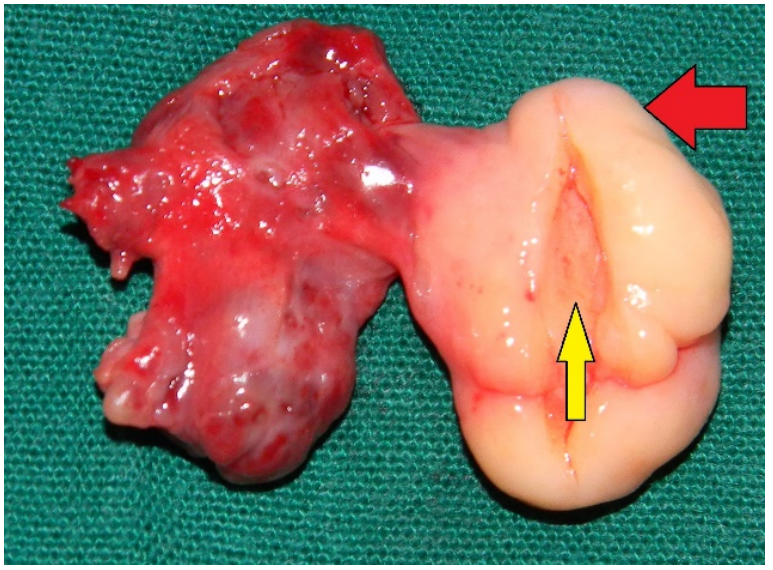

Figure 5. Cut section of the specimen showing soft lipomatous periphery (red arrow) and hard fibrous core (yellow arrow).

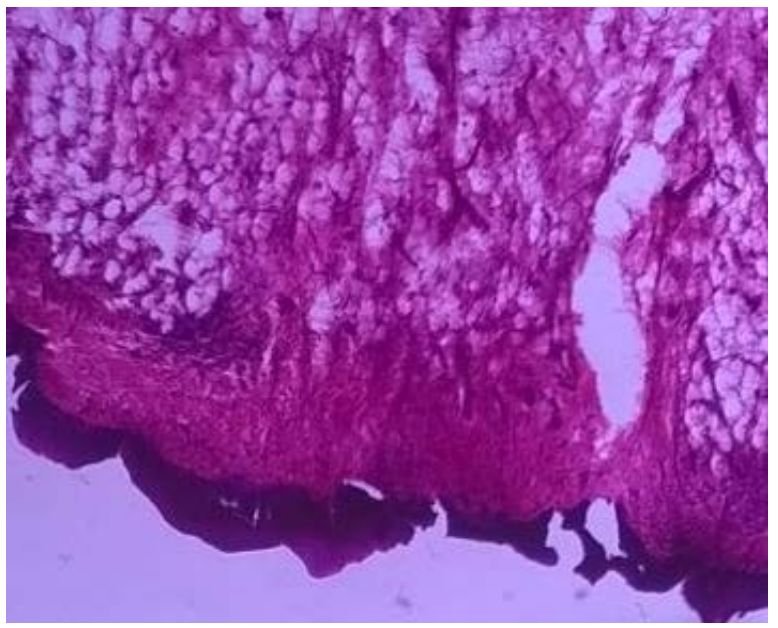

Figure 6. Histopathological examination showing lymphoid follicles with germinal centre covered with stratified squamous epithelium with sheets of adipose tissue and fibrous tissue in stroma (10× magnification with Hematoxillin and Eosin stain). 
papilloma has chances of malignant transformation. Rest are benign lesions but they might mimic like malignant lesions. In young adults, juvenile angiofibroma extension in oropharynx must be excluded. There are many previous publications on polypoidal lesions in tonsils like Halaas et al. [4] reported chondrolipoma. Many authors reported lipoma of tonsil like Wang et al. [5], Derekoy et al. [6], Raza et al. [7] and Dev et al. [8]. Fibrolipoma of tonsil was reported by Nandakumar et al. [9]. Kardon et al. [10] published a large series of 26 patients over 19 years with lymphangiomatous polyp of tonsils.

Fibrolipoma does not have specific age or sex predilection. In the past, fibrolipoma was considered as hamartoma. As per Begin and Frenkiel [11] the occurrence of a lipoma in the tonsil is plausible owing to the delicate mesenchymal framework present in the normal tonsil. Teratoma of tonsil may also have adipose tissue but presence of germ cells rules out the diagnosis. Treatment includes excision with or without tonsillectomy with either cold or hot methods [12].

\section{Conclusion}

Fibrolipoma of the tonsil is relatively rare benign peduculated polypoidal tumour. It may cause significant dysphagia, foreign body sensation, sleep apnoea and intubation difficulties. Differential diagnosis is very important from other benign and malignant lesions. Timely treatment is important for relieving symptoms and early histopathological examination for proper differential diagnosis.

\section{References}

[1] El-Monem, M.H.A., Gaafar, A.H. and Magdy, E.A. (2006) Lipomas of the Head and Neck: Presentation Variability and Diagnostic Work-Up. Journal of Laryngology and Otology, 120, 47-55. https://doi.org/10.1017/S0022215105004597

[2] Thakur, J.S., Saluja, M., Sharma D.R., et al. (2013) Fibrolipoma of Eustachian Ostium. BMJ Case Report 2013. https://doi.org/10.1136/bcr-2013-008794

[3] Ohtsuki, Y., et al. (2006) A Peduculated Hamartomatous Polyp of the Palatine Tonsil. Biomedical Research, 17, 155-158.

[4] Halaas, Y.P., Mra, Z. and Edelman, M. (2001) Chondrolipoma of the Oropharynx. Ear, Nose, \& Throat Journal, 80, 146-147.

[5] Wang, C.P., Kwan, P.C. and Ho, C.Y. (2007) Lipoma of the Palatine Tonsil. Journal of the Formosan Medical Association, 106, 673-675. https://doi.org/10.1016/S0929-6646(08)60026-1

[6] Derekoy, F.S., Fidan, H., Fidan, F., et al. (2007) Tonsillar Lipoma Causing Difficult Intubation: A Case Report. Kulak Burun Boğaz Íhtisas Dergisi, 17, 329-332.

[7] Raza, S.N., Waseem, Z., Reid, D. and Jackson, B.S. (2005) Giant Fibrovascular Polyp of the Oropharynx. Case Presentation and Literature Review. Journal of Otolaryngology, 34, 277-280. https://doi.org/10.2310/7070.2005.34418

[8] Dev, V.R., Heeringa, B. and Busch, R. (2000) Tonsilar Lipoma. Otolaryngology-Head and Neck Surgery, 122, 941. https://doi.org/10.1016/S0194-5998(00)70034-9

[9] Nandakumar, R., Inchara, Y.K., Ophelia, D’Souza, et al. (2010) Fibrolipoma of the 
Tonsil. Indian Journal of Pathology and Microbiology, 53, 562-563.

[10] Kardon, D.E., Wenig, B.M., Heffner, D.K., et al. (2000) Tonsillar Lymphangiomatous Polyps: A Clinicopathologic Series of 26 Cases. Modern Pathology, 13, 1128 1133. https://doi.org/10.1038/modpathol.3880208

[11] Begin, L.R. and Frenkiel, S. (1993) Polypoid Lipoma of the Palatine Tonsil. The Journal of Laryngology \& Otology, 107, 556-558. https://doi.org/10.1017/S0022215100123692

[12] Kanotra, S.P. and Davies, J. (2014) Management of Tonsillar Lipoma: Is Tonsillectomy Essential? Case Reports in Otolaryngology, 2014, Article ID: 451570.

Submit or recommend next manuscript to SCIRP and we will provide best service for you:

Accepting pre-submission inquiries through Email, Facebook, LinkedIn, Twitter, etc. A wide selection of journals (inclusive of 9 subjects, more than 200 journals)

Providing 24-hour high-quality service

User-friendly online submission system

Fair and swift peer-review system

Efficient typesetting and proofreading procedure

Display of the result of downloads and visits, as well as the number of cited articles Maximum dissemination of your research work

Submit your manuscript at: http://papersubmission.scirp.org/

Or contact ijohns@scirp.org 